\title{
CLINICAL AND HEMATOLOGICAL EVALUATION OF LEISHMANIASIS SERUM- POSITIVE DOGS IN RIO GRANDE DO SUL
}

\author{
HIRSCHMANN, Lourdes Caruccio ${ }^{1}$; \\ SIMON, Caroline Ferreira ${ }^{2}$; \\ BROD, Claudiomar Soares ${ }^{3}$; \\ RADIN, Jaqueline ${ }^{4}$; \\ ROSA, Cíntia Saydelles da ${ }^{5}$; \\ RECUERO, Ana Lúcia Coelho ${ }^{6}$.
}

\footnotetext{
${ }^{1}$ Médica Veterinária, UNIPAMPA, Campus Dom Pedrito, $R S ;{ }^{2}$ Doutoranda em Parasitologia, UFPEL, Pelotas, RS; ${ }^{3}$ Médico Veterinário, Professor, Doutor, Centro de Zoonoses, UFPEL, Pelotas, RS; ${ }^{4}$ Doutora em Parasitologia, UFPEL, Pelotas, RS; ${ }^{5}$ Doutoranda em Parasitologia, UFPEL, Pelotas, RS; ${ }^{6}$ Médica Veterinária, Doutora, UFPEL, Pelotas, $R S$.
}

\section{ABSTRACT}

V isceral leishmaniasis (VL) is a zoonotic infection causing chronic and systemic disease in numerous mammals. It is caused by the Leishmania (Leishmania) chagasi protozoan and transmitted by bites from the female phlebotomine Lutzomyia longipalpis. Rio Grande do Sul is a Brazilian state that was considered VL-free. However, in 2008, canine VL was detected in Western cities of the state. Lutzomyia longipalpis is the main vector of $V L$ and despite having a wide distribution in Brazil, only in 2009 was identified in São Borja, Rio Grande do Sul, in the urban area of the city. The present study evaluated the prevalence of canine $V L$ in kennels managed by local and non-governmental organizations, unstudied areas of Rio Grande do Sul. The dogs were subjected to general, tegumentary, and lymph node examinations. A complete blood count, parasitological and serological examinations were also performed. The serum-positive dogs showed dermatological lesions, normocytic normochromic anemia, thrombocytopenia and neutrophilic leukocytosis. Our investigation of non-endemic districts confirms the presence of oligosymptomatic dogs in Rio Grande do Sul.

Keywords: Leishmania. Clinic. Epidemiology. 


\section{INTRODUCTION}

Visceral leishmaniasis (VL) is a chronic parasitic disease caused by Leishmania (Leishmania) chagasi in Brazil (MAIA-ELKHOURY et al., 2008). This zoonotic infection is primarily found in rural areas, but VL has recently expanded to urban areas and emerged as a public health concern in Brazil and other regions of South America. This endemic disease is on the rise and is currently among the top six priority endemics worldwide (BRASIL, 2011).

VL is a systemic infectious disease that is endemic to Brazil and is considered important by the World Health Organization due to its wide geographical distribution and high potential lethality (MOREIRA, 2012). In Latin America, 90\% of cases occur in Brazil, with the highest prevalence in the Northeast region of the country and the lowest in the Southern region (BRASIL, 2011). Several mammalian species harbor the parasite, but the domestic dog is the primary host. Wild hosts include wild canis, rodents, opossums, and sloths (VILELA; MENDONÇA, 2013). L. chagasi is transmitted to humans and other vertebrate hosts during the blood feeding of Lutzomyia longipalpis, a specie of sandfly (LAINSON; RANGEL, 2005).

VL is controlled by the diagnosis and treatment of human cases, vector control and identification and euthanasia of reservoirs, particularly dogs (RIBEIRO, 2007). Treatment of dogs is not a recommended measure, as it does not lessen the importance of dogs as a reservoir of the parasite (BRASIL, 2006). The diagnosis is based on epidemiological data (endemic versus silent area), clinical presentation and laboratory examination. Until 2011, the Brazilian Ministry of Health recommended an enzyme-linked immunosorbent assay (ELISA) screening test and an indirect immunofluorescence assay (IFA) as confirmatory test. Later in 2012, the Brazilian Ministry of Health published a technical report stating the most efficient protocols were a fast chromatographic immunoassay as a screening test and an ELISA as a confirmatory test.

Rio Grande do Sul was considered VL-free until November 2008, when VL was suspected in a dog from São Borja. This triggered an epidemiological investigation in São Borja and other cities, which revealed the presence of Lutzomyia longipalpis vectors and Leishmania chagasi serum-positive dogs. The cities of São Borja and Uruguaiana were designated as 
transmission areas as they harbored the vector, human cases of VL and parasite-infected indigenous canines (CEVS/RS, 2011).

VL has broad clinical manifestations, ranging from asymptomatic to the classical presentation of parasitosis, evidenced by fever, anemia, hepatosplenomegaly, dry cough, leukopenia and hypergammaglobulinemia (OLIVEIRA et al., 2010). Dogs typically present skin lesions such as flaking and eczema, especially on the ears and nose. In later stages, dogs may present onychogryphosis, splenomegaly, lymphadenopathy, alopecia, dermatitis, keratoconjunctivitis, nasal discharge, lethargy, diarrhea, intestinal hemorrhage, swelling of the limbs and vomiting (ARRUDA, 2010). VL causes progressive weight loss, weakness, anorexia, mucocutaneous ulcers, conjunctivitis, onychogryphosis, hepatosplenomegaly, generalized lymphadenopathy, renal failure and death (CARDOSO, 2012).

To directly identify the parasite, a parasitological exam can be conducted on aspirate samples of lymph nodes, spleen and bone marrow (SUNDAR et al., 2002). Tissue imprinting can also be performed during necropsy; essentially, spleen tissue samples are imprinted onto microscope slides, fixed in methanol, and stained with Giemsa. Animals which do not show amastigotes in tissues are considered negative (TASCA et al., 2009).

Despite disagreements among some investigators (FERRER, 1999; KOUTINAS et al., 2001; MOREIRA et al., 2002), the parasitological exam is still considered the gold standard confirmatory test for VL diagnosis. Direct observation of amastigotes in aspirates from lymph nodes, bone marrow, spleen, liver, skin, and Giemsa or Leishman Panótico ${ }^{\circledR}$ stained blood is a safe, simple, fast, and minimally traumatic method of diagnosing disease. The specificity of direct observation is $100 \%$, but the sensitivity depends on the severity of parasitism, the specific tissue examined, the stain technique and the examiner.

The visceral leishmaniasis is a disease of public health significance and in the Rio Grande do Sul state, the diagnosis is not routinely performed. Thus, it is necessary an investigation aimed at analyzing aspects of the clinical and hematological evaluation of dogs in Rio Grande do Sul. 


\section{MATERIAL AND METHODS}

This study comprised a clinical, epidemiological and hematological evaluation of dogs in an intact region of Rio Grande do Sul, specifically municipalities from the Southern region and cities at the Western border of the state where the first outbreaks occurred. The total area encompassed 148,000 km² in 68 of 496 municipalities in Rio Grande do Sul. Within the study area, the health departments of the 68 cities were contacted by telephone; however, many officials claimed that there was no public kennel, while others refused to participate in the study due to concerns over discovering VL in the locale. Among those contacted, only 12 cities (17.6\%) agreed to participate in the study: São Francisco de Assis, Santiago, Dom Pedrito, Bagé, Alegrete, Caçapava do Sul, Cachoeira do Sul, Piratini, Arroio Grande, Capão do Leão, Rio Grande and Camaquã. A total of 165 animals (20\% males and 80\% females), randomly selected from kennels managed by non-governmental organizations or local groups in 12 cities from January 2011 to December 2012, were evaluated. It was not possible to evaluate a larger population due to time and cost restrictions on the analysis. We did not have access to the history of animals, because they are probably abandoned in the streets and captured from the kennels. A specific evaluation was made in dogs, however, it was not made new accompaniments.

The dogs were evaluated for the seropositivity using the old protocol (IFA and ELISA) and also using the current protocol recommended by Brazilian Ministry of Health. Samples from 165 dogs were collected and subjected to clinical, parasitological and epidemiological evaluation. Approximately 15 animals per city were randomly chosen and evaluated. This study was approved by the Ethics Committee for Animal Experimentation of the Federal University of Pelotas (CEEA/UFPEL/2134).

The dogs underwent a physical examination, including the heart rate, respiratory rate, rectal temperature, lymph node evaluation, mucosal color, and dermatologic evaluation, according as described by Nelson and Couto (2006).

Diagnosis of canine visceral leishmaniasis (CVL) was based on the direct observation of amastigotes of Leishmania spp. in fine-needle aspirates (FNA) of palpable lymph nodes, either the popliteal or the submandibular lymph nodes (Figures 1 and 2). The FNA was 
performed using a $25 \mathrm{G} \times 7 \mathrm{~mm}$ needle attached to a disposable $5 \mathrm{~mL}$ syringe. Each lymph node was aspirated twice with a single syringe, using a different needle each time. The aspirated tissue was then ejected onto glass slides and spread with a second slide using a squash technique. The slides were dried at room temperature and stained using the Fast Panotic ${ }^{\circledR}$ coloration (MEYER; RASKIN, 2012).

Blood (4 mL) was collected from the cephalic vein into EDTA tubes and sent for processing in the laboratory for evaluation of complete blood count (CBC). The hematological analysis was made in the Clinical Laboratory of Veterinary - UFPEL Hospital.

The animals were evaluated epidemiologically in relation to breed, gender, coat length, presence or absence of ectoparasites, time of collection (month of the year) and location in Rio Grande do Sul.

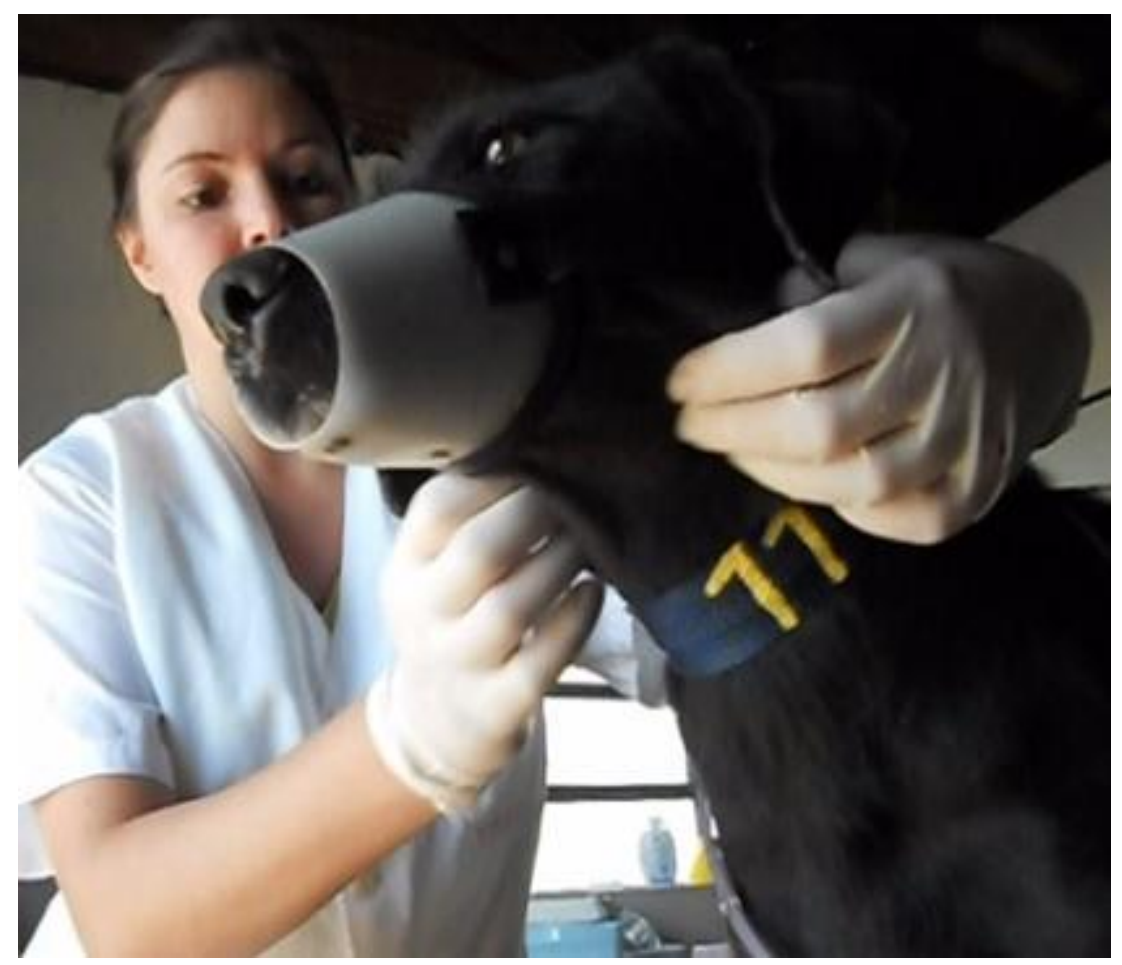

Figure 1 - Palpation of the submandibular lymph node. 


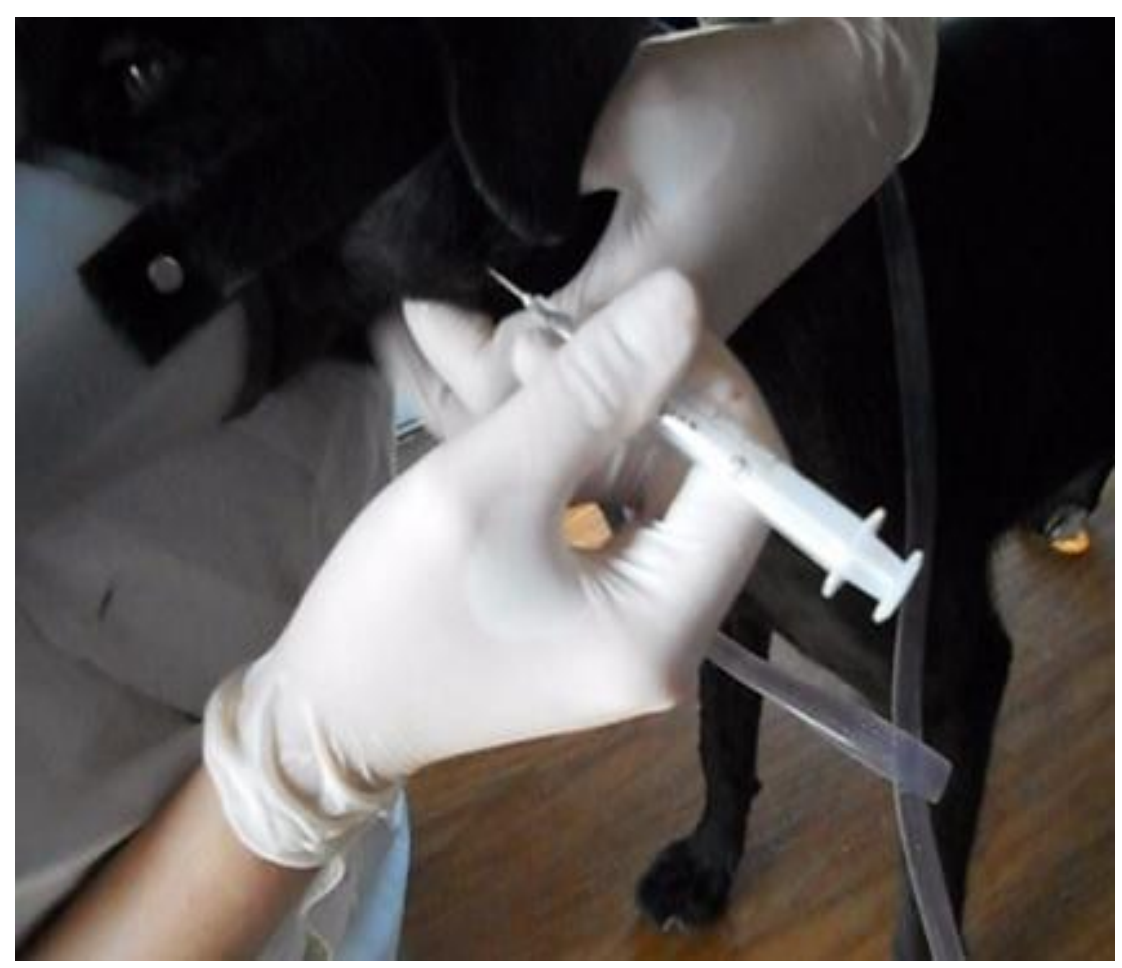

Figure 2 - Fine needle aspiration of the submandibular lymph node.

\section{RESULTS AND DISCUSSION}

Serum-positive dogs showed a variety of hematological abnormalities as follows: thrombocytopenia and eosinophilia (Dom Pedrito); normochromic normocytic anemia and thrombocytopenia (Rio Grande); neutrophilia and eosinopenia (Cachoeira do Sul); and normochromic normocytic anemia, thrombocytosis; and leukocytosis with neutrophilia (Cachoeira do Sul). The serum-positive dog from São Francisco de Assis showed no abnormalities on the complete blood count (CBC).

No amastigotes were observed on direct examination of the lymph node aspirates. A few samples were suspect, but no abnormalities were identified. However, $60 \%(3 / 5)$ of the serum-positive dogs showed abnormalities on lymph node palpation including enlargement (Rio Grande), enlargement with pain (São Francisco de Assis), and hardened lymph nodes (Cachoeira do Sul).

The clinical and epidemiological findings are summarized in Tables 1 and 2. The primary clinical signs in serum-positive dogs were lymphadenopathy (60\%) and dermatopathy (60\%). 
Less frequent clinical signs were dehydration (40\%) and weight loss (40\%). The least frequent clinical signs were mucosal discoloration (20\%), abnormal capillary refill time (CRT) (20\%), and ocular lesions (20\%). The heart rate and respiratory rate were within normal limits for all dogs, though the body temperature was slightly low at $38{ }^{\circ} \mathrm{C}$ in all serum-positive dogs.

Table 1 - Clinical findings in the five Leishmania chagasi serum-positive dogs from four cities in intact areas of Rio Grande do Sul during 2011-2012.

\begin{tabular}{|c|c|c|c|c|c|}
\hline \multirow[t]{3}{*}{ Clinical findings } & \multicolumn{5}{|c|}{ City } \\
\hline & Dom Pedrito & Rio Grande & São Francisco de Assis & Cachoeira do Sul & Cachoeira do Sul \\
\hline & Dog 1 & $\operatorname{Dog} 2$ & Dog 3 & Dog 4 & Dog 5 \\
\hline Hydration status & Hydrated & Dehydrated & Hydrated & Hydrated & Dehydrated \\
\hline Body condition & Normal & Cachectic & No change & No change & Lean \\
\hline Mucosa & Pale & Pink-Red & Pink-Red & Pink-Red & Pink-Red \\
\hline Capillary refill time & Normal & Normal & Normal & Abnormal & Normal \\
\hline Lymph nodes & Normal & Enlarged & Enlarged & Normal & Enlarged \\
\hline Skin lesion & Present & Present & Absent & Absent & Present \\
\hline Eye lesion & Absent & Present & Absent & Absent & Absent \\
\hline
\end{tabular}

Table 2 - Epidemiological findings in the five Leishmania chagasi serum-positive dogs from four cities in intact areas of Rio Grande do Sul during 2011-2012.

\begin{tabular}{|c|c|c|c|c|c|}
\hline \multirow{3}{*}{ Epidemiological Finding } & \multicolumn{5}{|c|}{ City } \\
\hline & Dom Pedrito & Rio Grande & São Francisco de Assis & Cachoeira do Sul & Cachoeira do Sul \\
\hline & Dog 1 & Dog 2 & Dog 3 & Dog 4 & Dog 5 \\
\hline Breed & German Shepard & Mongrel & Mongrel & Dachshund & Mongrel \\
\hline Gender & Male & Male & Female & Female & Female \\
\hline Coat length & Long & Medium & Short & Short & Short \\
\hline Ectoparasites & $\begin{array}{l}\text { Fleas and } \\
\text { Demodex spp. }\end{array}$ & Absent & Fleas & Fleas & Fleas \\
\hline Time of collection & December & September & April & July & July \\
\hline $\begin{array}{l}\text { Location in Rio Grande do } \\
\text { Sul }\end{array}$ & Southwest & South & Southwest & Center South & Center South \\
\hline
\end{tabular}

The CVL serum-positive dogs showed the following dermal lesions: ulceration, especially of the ears, and alopecia (Dom Pedrito); desquamation, alopecia, discoloration, and intradermal nodules (Rio Grande); and desquamation, alopecia, and ulceration lesions 
(Cachoreira do Sul). The dog in São Francisco de Assis was asymptomatic. All serum-positive dogs had dry fur.

In the parasitological examinations, amastigotes were not observed in any of the blood smears of serum-positive dogs. A previous study by Lira et al. (2006) showed that $42 \%$ of symptomatic dogs and serum-positive dogs on imunoenzimatic test (EIE) and indirect immunofluorescence assay (IFI) were negative on parasitological examination (gold standard), thus demonstrating that the parasitological test lacks adequate sensitivity. According to Campillo et al. (1999), bone marrow biopsy provides superior sensitivity to the lymph node aspirate. However, in this study, lymph node puncture was employed because it is less invasive and quicker. Amastigotes are easily visualized in samples from dogs with intense parasitism; otherwise, detecting the parasite in tissue can be quite challenging (FERRER et al., 1995).

In dogs displaying hematologic signs of leishmaniasis, normochromic normocytic anemia occurs due to decreased erythropoiesis caused by low serum levels of erythropoietin, ongoing inflammatory disease (primarily chronic), hypoplasia or aplasia of the bone marrow, nutritional deficiencies, or endocrine deficiencies. In $\mathrm{VL}$, the anemia is caused by the presence of the parasite in the bone marrow, which triggers an infiltration of lymphocytes, plasma cells, and macrophages into the bone marrow, and compromises erythrocyte production (COSTA-VAL et al., 2007). In parasitosis commonly characterized by splenomegaly, such as leishmaniasis, hemolytic anemia is a common finding due to the development of hypersplenism (FARID et al., 1969). Thrombocytopenia in leishmaniasis is caused by a reduction in the number of platelets due to vasculitis associated with a type III hypersensitivity reaction, increased of platelet catabolism, hepatopathy, and nephropathy (FELDMAN et al., 2000). According to Bulla et al. (2004) and Ciaramella et al. (2005), changes in the platelet population and function are most evident in symptomatic dogs resulting from the inflammatory process maintained by the immune system, as seen in ehrlichiosis and canine leishmaniasis. Other studies have shown that animals with leishmaniasis can develop neutrophilic leukocytosis (IKEDA et al., 2003; MEDEIROS et al., 2008). The initial phase of leishmaniasis reportedly induces leukocytosis associated with neutrophilia, though advanced 
stages often show leucopenia with lymphopenia (BOURDOISEAU et al., 1997). According to a study by Coutinho (2005), serum-positive dogs did not show an increase in the mean concentration of leukocytes; thus, leukocytosis was not considered a feature. In contrast, thrombocytopenia is a frequent finding in dogs with CVL. Leukocytosis is expected in any disorder that triggers an acute inflammatory response, including leishmaniasis. The normal leukocyte concentration observed in some CVL-positive animals may reflect the stage of disease. Maia (2013) observed hyperproteinemia, leukocytosis, and thrombocytopenia in dogs later diagnosed with VL. In the present study, the total plasma protein (TPP) concentration ranged between 7.2-8.2 g/dL, which is higher than the usual. High TPP is another abnormality often detected in leishmaniasis and other inflammatory processes.

Diagnosis using clinical signs in non-endemic areas is very difficult because the lesions of $\mathrm{VL}$ are similar to those in other canine diseases (KAGER, 1992). It is also important to remember that clinical signs depend on the virulence of the strain, inoculum dose, immunological state, nutritional status, and genetic traits of the host (SARAVIA et al., 1989; SCHRIEFER et al., 2005). In this study, the body temperature was slightly low at $38{ }^{\circ} \mathrm{C}$ in all serum-positive dogs. According to Bianchi et al. (2016) it was observed a serum-positive dog with hypothermia associated with progressive weight loss and appetite loss. In contrast, Feitosa et al. (2000) observed a temperature above $38^{\circ} \mathrm{C}$ in dogs with CVL.

The skin lesions observed in this study were ulceration, desquamation, alopecia, skin depigmentation, and intradermal nodules. Similar lesions were observed by Gonçalves (2010), with desquamation (53.33\%), alopecia (44.44\%), and ulceration (40\%) as the most frequent. Clinical changes were also reported, with pale mucous membranes the least common, consistent with the current study where only one dog (Dom Pedrito) had pale mucous membranes.

Ocular lesions were observed in only one dog from Rio Grande, which is likely due to the presence of intraocular parasites and deposition of immune complexes. These ocular changes are consistent with a report by Fulgêncio et al. (2008), who observed at least one ocular lesion in 76 of 200 (38\%) eyes in 100 dogs. They also reported intense mucopurulent 
discharge and heavy accumulation of mucoid secretion on the ocular surface. Similarly, Genaro (1993) observed pus in $25 \%$ of dogs studied.

In a study by Coutinho (2005), skin disorders (ulcers, dermatitis, and alopecia) were quite prevalent in CVL serum-positive dogs. Lima et al. (2004) also observed skin lesions such as dry desquamation (40.7\%) and alopecia (40.7\%). Moreira et al. (2013) observed conjunctivitis, cachexia, onychogryphosis, alopecia, desquamation, and skin ulceration, ranging in severity from localized lesions to widespread dissemination in animals with symptomatic CVL. Notably, in the current study, only localized lesions were observed.

The serum-positive dog from São Francisco de Assis was asymptomatic and lacked any skin lesions. In a study by Magalhães et al. (2012), 42\% of the asymptomatic dogs were CVL serum-positive, which highlights the importance of asymptomatic dogs as reservoirs for the parasite. Similarly, Silva et al. (2011) observed that 78\% (11 of 14) of CVL serum-positive dogs were asymptomatic, reinforcing the importance of silent reservoirs in the transmission of the parasite, as asymptomatic dogs do not attract the attention of owners and veterinarians, making it difficult to control the disease.

In the serum-positive dogs, $40 \%$ (2 of 5) were lean or cachectic. Lima et al. (2004) also observed emaciation and cachexia in CVL serum-positive dogs.

In this study, 60\% (3 of 5) of serum-positive dogs showed abnormal lymph nodes. According to Lima et al. (2004), the lymph nodes of serum-positive dogs were reactive and enlarged in all cases. Cardoso (2012) reported lymphadenopathy as one of the most frequent clinical signs in CVL serum-positive dogs. Barbosa et al. (2010) similarly reported lymphadenopathy as the most common clinical sign, occurring in $96.4 \%$ of CVL symptomatic dogs. This lymph node enlargement is the result of proliferation by B cells, plasma cells, histiocytes, and macrophages in lymphoid organs (FEITOSA, 2001).

The primary vector of CVL is the sand fly (Phlebotominae). However, an entomological survey of these insects has not been conducted in the 12 cities currently evaluated. We did observe that $80 \%$ ( 4 of 5 ) of the serum-positive dogs were flea infested, and the dogs may have encountered ticks or other ectoparasites prior to data collection. Recent studies, such as one by Coutinho et al. (2005), have described the transmission of L. chagasi by 
Rhipicephalus sanguineus in Brazil. Coutinho and Linardi (2007), while investigating the role of fleas (Ctenocephalides felis felis) on CVL transmission, observed that $1.9 \%$ of fleas collected from CVL serum-positive dogs contained promastigotes in Giemsa stained smears. This prevalence increased to $29.9 \%$ when PCR was used.

In our study, $60 \%$ (3 of 5 ) of the serum-positive dogs had short fur, which increases vulnerability to insect bites and the likelihood of infection. França-Silva et al. (2003) similarly observed that short-coated animals were more susceptible to bites from vectors than dogs with long coats. Carvalho-Filho (2008) also reported that short-coated dogs had higher odds of being serum-positive, and Rondon et al. (2008) observed that dogs with a short dark coat had a higher prevalence of the disease.

Most of the serum-positive dogs in this study were mixed breed; the only serum-reactive purebreds were a Daschund and a German Shepherd. There was no statistically significant difference in serum-positivity according to gender. França-Silva et al. (2003) also reported the absence of any breed predisposition disease prevalence, although others such as Miranda et al. (2008) demonstrated a breed predisposition for leishmaniasis in German Shepherds, Boxers, and Rottweilers, while Yorkshire Terriers and Poodles appeared to be resistant. Rondon et al. (2008) reported that neither gender was especially susceptible to CVL, and Nascimento (2011) observed that the risk of CVL infection was similar for both genders and among breeds, with no statistical differences noted. Almeida et al. (2010) also did not observe any statistically significant difference according to gender or breed.

VL was long restricted only to rural areas where the insect vector was found, but with urbanization, the disease has begun to spread into urban areas. CVL is primarily located in states with high temperatures and poor populations. As reported in the Brazilian Ministry of Health manual (2006), epidemiological data from the last 10 years indicate that VL presently occurs in both suburban and urban areas. Until the 1990s, most cases were reported in the Northeast region of Brazil. However, this study identified five cases of CVL in the Southern region of Brazil, a region considered non-endemic that encompasses a wide area of Rio Grande do Sul (extreme South, Southwest, and South Central). According to an epidemiological bulletin published by the CEVS/RS (2011), Rio Grande do Sul was considered 
VL-free area until November 2008, when CVL was suspected in a dog from São Borja. An epidemiological survey identified a serum-reactive canine sample in Santa Maria, and in Porto Alegre, the prevalence in December 2010 was $4.1 \%$ in 72 samples. Cities with suspected canine cases are those where serum-positive cases have been identified but no parasite has been isolated yet. The following cities are under investigation: Santa Cruz do Sul, Viamão, Cachoeira do Sul, São Luiz Gonzaga and Santo Ângelo (CEVS/RS, 2011).

According to Alves (2005), once the presence of L. (L.) chagasi/infantum is confirmed, serological samples should be collected in all dogs residing in the suspected area in order to assess the canine prevalence and determine the appropriate measures.

\section{CONCLUSION}

This study adds to the current knowledge of canine visceral leishmaniasis and should prompt the central health surveillance of the cities studied to enact the necessary control and preventive measures where CVL serum-positive dogs were identified. Serum-positive animals in non-endemic regions have few clinical and hematologic manifestations and are mostly oligosymptomatic. However, this epidemiological data is crucial as these asymptomatic or oligosymptomatic animals silently spread the disease.

\section{AVALIAÇÃO CLÍNICA E HEMATOLÓGICA DE CÃES SOROPOSITIVOS PARA LEISHMANIOSE NO RIO GRANDE DO SUL}

\section{RESUMO}

A Leishmaniose Visceral (LV) é uma zoonose de caráter crônico, sistêmica, que acomete diversos mamíferos, causada pelo protozoário Leishmania (Leishmania) chagasi, durante o repasto sanguíneo realizado pela fêmea do flebotomíneo Lutzomyia longipalpis. O Rio Grande do Sul era considerado um estado do Brasil sem casuística da doença, porém, em 2008, foram registrados casos autóctones de LV em municípios de região oeste do estado. Lutzomyia longipalpis é o principal vetor da LV e apesar de ter uma ampla distribuição no Brasil, apenas em 2009 foi identificado no município de São Borja, Rio Grande do Sul, no perímetro urbano da cidade. Este estudo foi realizado em uma área do RS sem diagnóstico para LV e foram avaliados cães provenientes de canis municipais ou ONG's. Os animais foram submetidos à avaliação clínica geral, sendo observadas principalmente lesões tegumentares e linfoadenopatias. Na avaliação laboratorial, realizou-se hemograma 
completo, exame parasitológico e sorológico. Os cães com exame sorológico positivo apresentaram sinais dermatológicos, anemia normocítica normocrômica, alterações plaquetárias e leucocitose com neutrofilia. Portanto, conclui-se que há presença de cães oligossintomáticos no Rio Grande do Sul.

Palavras-chave: Leishmania. Clínica. Epidemiologia.

\section{EVALUACIÓN CLÍNICA Y HEMATOLÓGICA DE PERROS SEROPOSITIVOS PARA LA LEISHMANIASIS EN RIO GRANDE DO SUL}

\section{RESUMEN}

a leishmaniasis visceral (LV) es una enfermedad zoonótica de naturaleza crónica, sistémica, que afecta a muchos mamíferos, causada por el protozoo Leishmania (Leishmania) chagasi, que se transmite por la hematofagia de la hembra del flebotomineo Lutzomyia longipalpis. El Rio Grande do Sul fue considerado un estado de Brasil sin casuística de la enfermedad, sin embargo, en 2008 se notificaron casos autóctonos de LV en los municipios de la región oeste del estado. Lutzomyia longipalpis es el principal vector de LV y a pesar de tener una amplia distribución en Brasil, sólo en 2009 se identificó en São Borja, Rio Grande do Sul, en el área urbana de la ciudad. Este estudio se llevó a cabo en el área del Rio Grande do Sul no diagnosticada por LV, donde se evaluaron los perros procedentes de perreras de las municipalidades $u$ organizaciones no gubernamentales. Los animales fueron sometidos a la evaluación clínica general, donde se observaron principalmente lesiones de los tejidos blandos y linfadenopatía. En pruebas de laboratorio, se realizó hemograma completo, examen parasitológico de heces y serología. Los perros seropositivos mostraron signos dermatológicos, anemia normocítica normocrómica, cambios de plaquetas y leucocitosis con neutrofilia. Por lo tanto, se concluye que hay presencia de perros oligosintomáticos en Rio Grande do Sul.

Palabras clave: Leishmania. Clínica. Epidemiología.

\section{ACKNOWLEDGMENTS}

The authors thank the Department of Biology and Parasitology at the Federal University of Pelotas, the Brazilian Ministry of Health, LACEN/RS, and UNIPAMPA. 


\section{REFERENCES}

ALMEIDA, A. B. P. F.; MENDONÇA, A. J.; SOUSA, V. R. F. Prevalência e epidemiologia da leishmaniose visceral em cães e humanos, na cidade de Cuiabá, Mato Grosso, Brasil. Ciência Rural, v. 40, n. 7, p. 1610-1615, 2010.

ALVES, W. A. Controle da Leishmaniose Visceral Baseado no Reservatório Canino. In: Consulta de Expertos OPS/OMS sobre Leishmaniosis Visceral en Las Américas [online]. 2005 [cited 2013 Apr 25]. Available from: <http://bvs1.panaftosa.org.br/local/File/textoc/LEANES_Inf_final_leish_2005.pdf\#page=98>

ARRUDA, M. M. Programa de Zoonoses - Região Sul. Leishmanioses. Manual de Zoonoses [online]. 2010 [cited 2012 Nov 25]. Available from:

<http://www.crmvsc.org.br/arquivos/Manual-de-Zoonoses-I.pdf>

BARBOSA, D. S.; ROCHA, A. L.; SANTANA, A. A.; SOUZA, C. S. F.; DIAS, R. A.; COSTA-JÚNIOR, L. M.; ABREU-SILVA, A. L. Soroprevalência e variáveis epidemiológicas associadas à leishmaniose visceral canina em área endêmica no município de São Luís, Maranhão, Brasil. Ciência Animal Brasileira, v. 11, p. 653-659, 2010.

BIANCHI, M. V.; FREDO, G.; TAGLIARI, N. J.; FILHO, R. V. L.; LORENZO, C.; LUPION, C. G.; DRIEMEIER, D.; SONNE, L. Leishmaniose Visceral Canina autóctone na região urbana de Porto Alegre, RS, Brasil. Acta Scientiae Veterinariae, v. 44, n. 1, p. 110, 2016. [cited 2016 Apr 12]. Available from: <http://www.redalyc.org/pdf/2890/289043698001.pdf>

BOURDOISEAU, G.; BONNEFONT, C.; MAGNOL, J. P.; SAINT-ANDRÉ, L.; CHABANNE, L. Lymphocyte subset abnormalities in canine leishmaniasis. Vet Immunol Immunopathol, v. 56, n. 3-4, p. 345-351, 1997.

BRASIL. Ministério da Saúde, Secretaria de Vigilância em Saúde, Departamento de Vigilância Epidemiológica. Manual de vigilância e controle da leishmaniose visceral [online]. 2006 [cited 2012 Nov 29]. Available from:

<http://portal.saude.gov.br/portal/arquivos/pdf/manual_leish_visceral2006.pdf>

BRASIL. Ministério da Saúde, Secretaria de Vigilância em Saúde. Doenças de A a Z, Leishmaniose visceral [online]. 2011 [cited 2011 Nov 27]. Available from: <http://portal.saude.gov.br/portal/saude/profissional/area.cfm?id_area=1561>

BULLA, C.; TAKAHIRA, R. K.; ARAÚJO, J. P.; TRINCA, L. A.; LOPES, R. S.; WIEDMEYER, C. E. The relationship between the degree of thrombocytopenia and infection with Ehrlichia canis in an endemic area. Veterinary Research, v. 35, p. 141-146, 2004.

CAMPILLO, M. C.; VAZQUEZ, F. A. R.; FERNANDEZ, A. R. M.; ACEDO, M. C. S.; et al. In: BAÑOS, P. D.; ROMERON, H. Q.; VARELA, M. C. Parasitologia Veterinária. Madrid: McGraw-Hill Interamericana, 1999. p. 651-665. 
CARDOSO, S. P. Leishmaniose visceral canina (LVC): Revisão de Literatura e Estudo Comparativo entre as Técnicas de Citopatologia, Histopatologia e Imunohistoquímica no Diagnóstico da LVC em Cães naturalmente infectados do Distrito Federal. Brasília: UnB, 2012. 71p. Monografia (Graduação em Medicina Veterinária), Faculdade de Medicina Veterinária e Agronomia, Universidade de Brasília, 2012.

CARVALHO-FILHO, N. W. B. Aspectos epidemiológicos e soroprevalência da Leishmaniose e Babesiose em cães de raça no município de São Luís - MA. São Luís, UEM, 2008, 51p. Dissertação (Mestrado em Ciências Veterinárias - Sanidade Animal), Universidade Estadual do Maranhão, 2008.

CEVS/RS. Leishmaniose visceral no Rio Grande do Sul. Boletim epidemiológico, Porto Alegre-RS [online]. 2011; 13 (1) [cited 2012 Nov 30]. Available from: <http://www.saude.rs.gov.br/upload/1337355106_v.13,\%20n.1,\%20mar.,\%202011.pdf>

CIARAMELLA, P.; PELAGALLI, A.; CORTESE, L.; et al. Altered platelet aggregation and coagulation disorders related to clinical findings in 30 dogs naturally infected by Leishmania infantum. The Veterinary Journal, v. 169, p. 465-467, 2005.

COSTA-VAL, A. P.; CAVALCANTI, R. R.; GONTIJO, N. F.; et al. Canine visceral leishmanisis: Relationships between clinical status, humoral immune response, haematology, and Lutzomyia (Lutzomyia) Longipalpis infectivity. The Veterinary Journal, v. 174, n. 3, p. 636643, 2007.

COUTINHO, J. F. V. Estudo clinico-laboratorial e histopatológico de cães naturalmente infectados por Leishmania chagasi com diferentes graus de manifestação clínica. Natal: UFRN, 2005. 106p. Dissertação (Mestrado em Bioquímica), Departamento de Bioquímica, Universidade Federal do Rio Grande do Norte, 2005.

COUTINHO, M. T.; BUENO, L. L.; STERZIK, A.; et al. Participation of Rhipicephalus sanguineus (Acari: Ixodidae) in the epidemiology of canine visceral leishmaniasis. Veterinary Parasitology, v. 128, p. 149-155, 2005.

COUTINHO, M. T. Z.; LINARDI, P. M. Can fleas from dogs infected with canine visceral leishmaniasis transfer the infection to other mammals? Veterinary Parasitology, v. 147, p. 320-325, 2007.

FARID, Z.; PATWARDHAN, V. N.; DARBY, W. J. Parasitism and Anemia. The American Journal of Clinical Nutrition, v. 22, n. 5, p. 498, 1969.

FEITOSA, M. M.; IKEDA, F. A.; LUVIZOTTO, M. C. R.; PERRI, S. H. V. Aspectos clínicos de cães com leishmaniose visceral no município de Araçatuba-São Paulo (Brasil). Clínica Veterinária, v. 28, p. 36-44, 2000. 
FEITOSA, M. M. Leishmaniose Visceral: um desafio crescente. Revista Intervet Pet, p. 1-15, 2001.

FELDMAN, B. V.; ZINKL, J. G.; JAIN, N. C. Schalm's Veterinary Hematology. Canada: Lippincott Williams \& Wilkins. 2000.

FERRER, L.; AISA, M. J.; ROURA, X.; et al. Serological Diagnosis and Treatment of Canine Leishmaniasis. Veterinary Record, v. 136, n. 20, p. 514-516, 1995.

FERRER, L. M. Clinical aspects of canine leishmaniasis. In: INTERNATIONAL CANINE LEISHMANIASIS FORUM, 1999, Barcelona, Spain. Proceedings. Sumène, France: Hoechst Roussel Vet., 1999. p. 6-10.

FRANÇA-SILVA, J. C.; COSTA; R. T.; SIQUEIRA, A. M.; et al. Epidemiology of canine visceral leishmaniasis in the endemic area of Montes Claros municipality, Minas Gerais State, Brazil. Veterinary Parasitology, v. 111, p. 161-173, 2003.

FULGÊNCIO, G. O.; VIANA, F. A. B.; BORGES, K. D. A. Oftalmopatias associadas à leishmaniose visceral canina - revisão de literatura. Revista do Conselho Federal de Medicina Veterinária, v. 45, p. 31-41, 2008.

GENARO, O. Leishmaniose Visceral Canina Experimental. Belo Horizonte, UFMG, 1993, 202p. Tese (Doutorado em Parasitologia), Instituto de Ciências Biológicas, Universidade Federal de Minas Gerais, 1993.

GONÇALVES, B. S. Leishmaniose visceral canina na área urbana de Cuiabá-MT: comparação de técnicas laboratoriais, tentativa de desenvolvimento de metodologia para o diagnóstico e caracterização da espécie de Leishmania circulante em amostra selecionada. Rio de Janeiro, ENSP, 2010, 125p. Dissertação (Mestrado em Saúde Pública), Escola Nacional de Saúde Pública Sergio Arouca, Fundação Oswaldo Cruz, 2010.

IKEDA, F. A.; LUVIZOTTO, M. C. R.; GONÇALVES, M. E.; et al. Perfil hematológico de cães naturalmente infectados por Leishmania chagasi no município de Araçatuba, São Paulo (Brasil): um estudo retrospectivo de 191 casos. Clínica veterinária, v. 47, p. 42-48, 2003.

KAGER, P. A. Splenic aspiration in visceral leishmaniasis. Revista da Sociedade Brasileira de Medicina Tropical, v. 25, n. 4, Editorial, p. 217-223, 1992.

KOUTINAS, A. F.; SARIDOMICHELAKIS, M. N.; MYLONAKIS, M. E.; et al. A randomised, blinded, placebo-controlled clinical trial with allopurinol in canine leishmaniosis. Veterinary Parasitology, v. 98, p. 247-261, 2001.

LAINSON, R.; RANGEL, E. F. Lutzomyia longipalpis and the eco-epidemiology of American visceral leishmaniasis, with particular reference to Brazil: a review. Memórias do Instituto Oswaldo Cruz, Rio de Janeiro, v. 100, p. 811-827, 2005. 
LIMA, W. G.; MICHALICK, M. S.; DE MELO, M. N.; et al. Canine visceral leishmaniasis: a histopathological study of lymph nodes. Acta Tropica, v. 92, n. 1, p. 43-53, 2004.

LIRA, R. A.; CAVALCANTI, M. P.; NAKAZAWA, M.; et al. Canine visceral leishmaniosis: A comparative analysis of the EIE-leishmaniose-visceral-canina-Bio-Manguinhos and the IFIleishmaniose-visceral-canina-Bio-Manguinhos Kits. Veterinary Parasitology, v. 137, p. 11-16, 2006.

MAGALHÃES, L. F.; WILSON, T. M.; MEDEIROS, A. A. Quadro clínico de cães com Leishmaniose Visceral e sua correlação com a sensibilidade do teste parasitológico. Veterinária Notícias, Uberlândia, v. 18, n. 2 (supl.), p. 67-72, 2012.

MAIA-ELKHOURY, A. N.; ALVES, W. A.; SOUSA-GOMES, M. L.; et al. Visceral leishmaniasis in Brazil: trends and challenges. Cadernos de Saúde Pública, v. 24, p. 2941-2947, 2008.

MAIA, L. S. Leishmaniose visceral canina: Aspectos clínicos e hematológicos de casos suspeitos e confirmados atendidos no Hospital Veterinário da Universidade de Brasília em 2011. Brasília, UnB, 2013, 23p. Monografia (Conclusão do Curso de Medicina Veterinária) Faculdade de Agronomia e Medicina Veterinária, Universidade de Brasília; 2013.

MEDEIROS, C. M. O.; MELO, A. G. C.; LIMA, A. K. F.; et al. Perfil hematológico de cães com leishmaniose visceral no município de Fortaleza, Ceará. Ciência Animal, v. 8, n. 1, p. 43-50, 2008.

MEYER, D. J.; RASKIN, R. E. Citologia clínica de cães e gatos: atlas colorido e guia de Interpretação. 2. ed. Philadelphia: W. B. Saunders, p. 1-14, 2012.

MIRANDA, S.; ROURA, X.; PICADO, A.; et al. Characterization of sex, age, and breed for a population of canine leishmaniosis diseased dogs. Research in Veterinary Science, v. 85, p. 35-38, 2008.

MOREIRA, E. A. Aspectos hematológicos de pacientes com leishmaniose visceral. Academia de Ciência e Tecnologia, São José do Rio Preto, SP, Março, 2012. Available from:

$<$ http://www.ciencianews.com.br/arquivos/ACET/IMAGENS/revista_virtual/hematologia/he mato21.pdf>

MOREIRA, M. A. B.; LUVIZOTTO, M. C. R.; NUNES, C. M.; et al. Application of direct immunofluorescence technic for the diagnosis of canine visceral leishmaniaisis in lymph nodes aspierate. Brazilian Journal of Veterinary Research and Animal Science, v. 39, n. 2, p. 103-106, 2002.

MOREIRA, P. R. R.; BANDARRA, M. B.; MAGALHÃES, G. M.; et al. Influence of apoptosis on the cutaneous and peripheral lymph node inflammatory response in dogs with visceral leishmaniasis. Veterinary Parasitology, v. 192, p. 149-157, 2013. 
NASCIMENTO, G. S. M. Aspectos epidemiológicos da leishmaniose visceral canina nas regiões administrativas Lago Norte e sobradinho II do Distrito Federal - DF. Goiânia, UFG, 2011, 53p. Dissertação (Mestrado em Sanidade Animal), Escola de Veterinária e Zootecnia, Universidade Federal de Goiás, 2011.

NELSON, R. W.; COUTO, C. G. Medicina Interna de Pequenos Animais. 3. ed. Rio de Janeiro: Elsevier, 2006. p. 625-633.

OLIVEIRA, J. M.; FERNANDES, A. C.; DORVAL, M. E.; et al. Mortalidade por Leishmaniose Visceral: aspectos clínicos e laboratoriais. Sociedade Brasileira de Medicina Tropical SBMT, v. 43, n. 2, p. 188-193, 2010.

RIBEIRO, V. M. Leishmaniose visceral canina-Desafio Permanente. Espaço CRMV-MG [online]. 2007 [cited 2012 Nov 29]. Available from:

<http://www.anclivepabrasil.com.br/portal_v2/es_crmv.php?id=22>

RONDON, F. C.; BEVILAQUA, C. M.; FRANKE, C. R.; et al. Cross-sectional serological study of canine Leishmania infection in Fortaleza, Ceará state, Brazil. Veterinary Parasitology, v. 155, p. 24-31, 2008.

SARAVIA, N. G.; VALDERRAMA, L.; LABRADA, M.; HOLGUÍN, A. F.; NAVAS, C.; PALMA, G.; WEIGLE, K. A. The relationship of Leishmania braziliensis subspecies and immune response to disease expression in New World leishmaniasis. Journal of Infectious Diseases, v. 159, n. 4, p. 725-735, 1989.

SCHRIEFER, A. L. F.; SOUSA, R. S.; GUIMARÃES, L. H.; NETO-GOES, A.; SCHRIEFER, A. Papel do Parasita e do Hospedeiro na Expressão Clínica das Leishmanioses. Gazeta Médica da Bahia, v. 75, n. 1, p. 46-56, 2005.

SILVA, D. A.; MADEIRA, M. F.; TEIXEIRA, A. C.; et al. Laboratory tests performed on Leishmania seroreactive dogs euthanized by the Leishmaniasis control program. Veterinary Parasitology, v. 179, p. 257-261, 2011.

SUNDAR, S.; PAI, K.; SAHU, M.; et al. Immunochromatographic strip-test detection of antiK39 antibody in Indian Visceral Leismaniasis. Annals of Tropical Medicine and Parasitology, v. 96, n. 1, p. 19-23, 2002.

TASCA, K. I.; BUZETTI, W. A. S.; TENORIO, M. S.; et al. Exames parasitológicos, imunoistoquímicos e histopatológicos para detecção de Leishmania chagasi em tecidos esplênicos de cães com leishmaniose visceral. Revista Brasileira de Parasitologia Veterinária, Jaboticabal, v. 18, n. 1, p. 27-33, 2009. 
VILELA, M.; MENDONÇA, S. Leishmaniose. Agência Fiocruz de Notícias. Instituto Oswaldo Cruz; 2013. Available from: <https://agencia.fiocruz.br/leishmaniose>

Corresponding author: Lourdes Caruccio Hirschmann. Rua 21 de abril, n. 80, Dom Pedrito, RS. CEP 96450-000. lourdescaruccio@gmail.com 